Rea Tot $^{1}$

doc. dr. sc. Ivan Dunđer ${ }^{2}$

\title{
PRIMJENA I ZNAČAJ PROCESA LOKALIZACIJE VIDEO IGARA
}

\author{
Pregledni rad / Review \\ UDK/UDC: 379.82:004 \\ DOI: $10.51650 /$ ezrvs.15.1-2.6 \\ Primljeno / Received: 19/5/2021 \\ Prihvaćeno / Accepted: 20/6/2021
}

S ubrzanim razvojem i velikim rastom popularnosti video igara, u posljednjih nekoliko godina industrija video igara doživjela je značajan proces globalizacije. Video igre danas su bitan faktor u industriji digitalne zabave i privlače mnoge igrače, bez obzira na spol, dob, društveni, politički ili ekonomski status. Ta popularnost i brz razvoj video igara dovode do sve veće potrebe da tvrtke svoje video igre učine dostupnim što većem broju ljudi kako bi se postigao visok povrat financijskih ulaganja. Stoga je očita želja i potreba da se video igre ciljano prilagode svim potencijalnim korisnicima, ma gdje god se oni nalazili. To je iznimno važan čimbenik zadovoljstva igrača, i kao takav vrlo je važan u savladavanju jezične barijere, promociji međunarodnog imidža tvrtke te postizanju dobrih poslovnih rezultata. No, to znači da je video igru potrebno prilagoditi velikom broju jezika, kulturnim razlikama, načinima govora i razmišljanja, a ujedno kako bi se uklonilo sve ono što nije prikladno za ciljano tržište. Jedno od mogućih rješenja za prilagodbu međunarodnom tržištu svakako je lokalizacija, čijom se primjenom nastoje zadovoljiti potrebe svih igrača i tržišta. Video igre, međutim, imaju specifične značajke koje ih razlikuju od ostalih medija, budući da su u središtu interakcija igrača i grafički elementi igre, što je jedinstveno u odnosu na prevođenje romana ili igranog filma. Ovaj rad daje pregled strategija za prilagodbu video igara te karakteristike tijeka prilagodbe, s posebnim osvrtom na pristup lokalizacije kao i probleme i otvorena pitanja u procesu prilagodbe video igara međunarodnom tržištu.

Ključne riječi: obrada prirodnog jezika, lokalizacija, internacionalizacija, jezične tehnologije, video igre.

\section{Uvod}

Video igre su medij koji neprestano raste i dobiva na popularnosti diljem svijeta. Danas su globalni fenomen sposoban pridonošenju prihoda koliko i filmska industrija³. Razvojem

\footnotetext{
1 Sveučilište u Zagrebu, Filozofski fakultet, Odsjek za informacijske i komunikacijske znanosti, e-mail: rea.tot@gmail.com

2 Sveučilište u Zagrebu, Filozofski fakultet, Odsjek za informacijske i komunikacijske znanosti, e-mail: ivandunder@ gmail.com

3 Bernal Merino, M. (2006.) On the Translation of Video Games, The Journal of Specialised Translation, God. 6, str. 22-36
} 
samih video igara javlja se i potreba za njihovom prilagodbom svim potencijalnim korisnicima, gdje god se oni nalazili. Jedan od mogućih pristupa prilagodbe video igara ciljanim tržištima svakako je lokalizacija. Ideja lokalizacije video igara počela se razmatrati kao mogućnost tek sredinom 1990-ih ${ }^{4}$, no tada je jedan od problema bila ograničena količina prostora potrebnog za smještaj tekstualnih nizova koji su bili duži od izvornika. Tehnologija se početkom 21. stoljeća razvila i omogućila pohranjivanje teksta u tekstualne nizove omogućavajući time učinkovitiju obradu i više prostora za pohranu. Bolje audio mogućnosti i oslanjanje na glasovnu glumu danas stvaraju nove izazove kod kojih treba omogućiti sinkronizaciju ili prevođenje i snimanje novoga zvuka ${ }^{5}$. Kako se računalna grafika poboljšavala, a video igre su se sve više oslanjale na računalno generirane slike, animacije i kinematografske franšize, više pažnje moralo se također posvetiti i sinkronizaciji usana kao i vizualnim gestama koje bi mogle biti kulturno specifične ${ }^{6}$. Stoga je lokalizacija video igara postala neophodan dio ciklusa proizvodnje i plasiranja igara na globalnom tržištu ${ }^{7}$ te se potreba za njom pojavila kako bi se pripremile različite inačice proizvoda i usluga za različita ciljana tržišta ${ }^{8}$. Lokalizacija je popularna i izvan svijeta prilagodbe video igara i može se primijeniti i na druge oblike softvera. Stoga se općenito može reći da predstavlja proces koji tvrtke primjenjuju kako bi zadovoljile međunarodna tržišta ${ }^{9}$ te se provodi jer se dovođenje softvera na globalno tržište smatra ključnim za jamčenje uspjeha i dugovječnosti proizvoda ${ }^{10}$.

\section{Strategije prilagodbe video igara za međunarodno tržište}

Lokalizacija i internacionalizacija dvije su osnovne strategije koje treba uzeti u obzir prilikom oblikovanja međunarodnih inačica video igara. Internacionalizacija predstavlja oblikovanje proizvoda na način da se može prilagoditi izdavanju u drugim zemljama bez potrebe za promjenom dizajna proizvoda, što podrazumijeva da je proizvod ili usluga od početka oblikovana na način koji bi se zadovoljile potrebe tržišta u velikom broju zemalja ${ }^{11}$. Cilj internacionalizacije je stvoriti proizvod ili uslugu koja se lako može lokalizirati uz minimalnu količinu posla od strane programera. U kontekstu video igara to obuhvaća iste značajke igre, funkcionalnost i iskustvo igranja, kako bi sve bilo prisutno u različitim međunarodnim inačicama video igre. To znači da su korisničko sučelje (engl. user interface, UI), sadržaj igre i drugi elementi dizajnirani na način da budu prilagodljivi različitim inačicama i međunarodnom tržištu. Na primjer, zasloni korisničkog sučelja oblikovani su za smještaj tradicionalnog europskog teksta koji se čita slijeva udesno i hebrejskog teksta koji se čita zdesna ulijevo. To isto tako znači da se svi formati datuma, vremena i valuta mogu integrirati u video igru'2.

\footnotetext{
${ }^{4}$ Ibid.

5 O'Hagan, M. i Mangiron, C. (2013.), Game Localization, John Benjamins Publishing Company, Amsterdam/Philadelphia

${ }^{6}$ Maxwell Chandler, H. i O'Malley Deming, S. (2012.), The Game Localization Handbook (2. ed.), Jones \& Barlett Learning

7 https://www.sinonim.hr/blog/4718-2/

8 Mangiron, C. i O'Hagan, M. (2006.) Game Localisation: Unleashing Imagination with "Restricted" Translation, The Journal of Specialised Translation, God. 6, str. 10-21

9 Bernal Merino, M. (2008.) CREATIVITY IN THE TRANSLATION OF VIDEO GAMES, Quaderns de Filologia, Estudis Literaris, God. 13, str. $57-70$

10 https://blog.andovar.com/games-translation-ultimate-guide

11 https://www.investopedia.com/terms/i/internationalization.asp

12 Maxwell Chandler, H. i O'Malley Deming, S. (2012.), The Game Localization Handbook (2. ed.), Jones \& Barlett Learning
} 
Međunarodni korisnici trebali bi imati osjećaj da je proizvod izrađen posebno za njih te da imaju jednako igračko iskustvo kao i korisnici izvornog jezika. Primjerice, ako će se neka burzovna igra objaviti u Sjedinjenim Američkim Državama i Europi, igra bi trebala podržavati međunarodne formate valuta i pravilnu pretvorbu valuta. Ako igra ima značajku koja omogućava igraču da prilagodi lik, urednik likova trebao bi sadržavati izbor različitih rasa i nacionalnosti. Ovakvi detalji iznimno su važni igračima i daju tvrtkama bolju reputaciju na tržištu. Ukratko, internacionalizacija jest način na koji se može osigurati da su proizvod ili usluga razvijeni na način da se proces lokalizacije može relativno lako provesti ${ }^{13,14}$.

Kao što je već ranije naznačeno, lokalizacija je sam postupak prevođenja jezičnih elemenata u igri na druge jezike. $U$ usporedbi s internacionalizacijom, lokalizacija je izravna jer se tiče samo jezičnih sredstava ${ }^{15}$. Ako je proizvod pravilno internacionaliziran, video igru neće trebati redizajnirati ili dodati posebne značajke kako bi se prilagodila prijevodima. To čini stvarni proces lokalizacije prilično bezbolnim. Stvaranje japanske ili ruske inačice mnogo je jednostavnije ako igra već prikazuje naglašene znakove, predviđa međunarodne rasporede tipkovnice i nema kulturno specifične reference koje bi trebalo ispraviti ${ }^{16}$. Može se isto tako reći da je lokalizacija proces prilagodbe nekog proizvoda ili usluge kako bi se osigurala usklađenost s potrebama željenog tržišta, posebno s osvrtom na različita jezična, kulturna i geografska područja ${ }^{17}$, pri čemu treba uzeti u obzir i sva kulturalna, etnička i geopolitička obilježja, povijest, religiju i sl. Lokalizacija se najčešće odnosi na prilagodbu u prevođenju samoga softvera, različitih inačica aplikacija za pametne telefone i ostale platforme, sadržaja na webu, web alata, uputa za korištenje, raznih priručnika, pa sve do pakiranja proizvoda itd. Naravno da to uključuje i prijevod svih tekstova u video igrama ${ }^{18}$, ali i transkripte audio materijala te drugih komponenti video igre. Lokalizacija može biti provedena samo djelomično, ali ukoliko se provodi u cijelosti, ona može uključivati i prilagodbu dizajna, grafičkih elemenata, marketinških poruka i ostalih elemenata koji su bitni za određeno tržište.

Uspješno lokaliziran proizvod ili usluga je ona za koju se čini da je razvijena baš za područje neke lokalne kulture ili sredine i stoga se u obzir moraju uzeti i detalji kao što su korištene vremenske zone, valute, državni praznici, nazivi nekih proizvoda ili usluga, neke zemljopisne reference ili reference na popularnu kulturu. Taj proces prevođenja jezika može se olakšati i ubrzati automatskim prevođenjem jezika putem sustava za automatsko strojno prevođenje, no vrlo često je potrebna dodatna obrada teksta kako bi se optimiziralo prilagođavanje i podešavanje teksta za sintaksu jezika kao i za idiomatski jezik nekog određenog područja. Međutim, i sami prevoditelji video igara preferiraju raditi bez navedenih sustava za automatizaciju prevođenja, pošto proces prijevoda shvaćaju više kao kreativan proces povezan više s prijevodom literarnih sadržaja nego prijevodom softvera ${ }^{19}$. Ipak, ne može se reći da su lokalizacija nekog sadržaja i prevođenje isti postupak, jer je to samo djelomično točno. $U$ nekim slučajevima nema bitne razlike između prevođenja i lokalizacije, no, lokalizacija osim

\footnotetext{
13 https://searchcio.techtarget.com/definition/localization

${ }_{14}$ Maxwell Chandler, H. i O'Malley Deming, S. (2012.), The Game Localization Handbook (2. ed.), Jones \& Barlett Learning

15 Ibid.

16 Ibid.

17 https://searchcio.techtarget.com/definition/localization

18 https://lektor.hr/hr/usluga/lokalizacija-7

19 Mangiron, C. (2018.) Game on! Burning issues in game localisation, Journal of Audiovisual Translation, God. 1, Br. 1, str. 122-138
} 
samog postupka prevođenja obuhvaća i prilagodbu već ranije navedenih elemenata. Pored navedenih elemenata lokalizacijom se moraju obuhvatiti i izbor boja te kulturne reference kako proizvodi ili usluge ne bi ispale uvredljive i neprikladne. Zato je potrebno dubinsko proučavanje ciljanog tržišta i kulture kako bi se proizvod ili usluga prilagodila lokalnim potrebama te kako bi se stekao dojam da proizvod potječe upravo iz te sredine ${ }^{20}$. Proces lokalizacije može se izvršiti za čitave regije ili pak zemlje u kojima ljudi govore različite jezike ili se koriste različitim dijalektima. Npr. različiti njemački dijalekti s različitim idiomima prisutni su u Njemačkoj, Austriji, Švicarskoj i Belgiji ${ }^{21}$. Sve ove promjene unutar lokalnih kultura i sredina potrebno je prepoznati kako bi se izbjegle i poštovale kulturne osjetljivosti, potencijalan sukob s lokalnom kulturom, običajima i navikama. To je izrazito važno jer omogućuje uspješno plasiranje na lokalnom tržištu ${ }^{22}$. S druge strane, klasično prevođenje teksta odnosi se na generiranje prijevoda teksta na ciljani jezik kako bi informaciju napisanu na jednom jeziku mogli razumjeti govornici drugog jezika ${ }^{23}$.

Istraživanja pokazuju da će više od 70\% potencijalnih kupaca prije kupiti proizvod ili uslugu ako su informacije dane na njihovom materinskom jeziku²4. Navedeno je, da je to čak i važnije od same cijene proizvoda. Ističe se kako lokalizacijom tvrtke pokazuju da misle na svoje korisnike i kupce te da su spremne prilagoditi se njihovom jeziku i kulturi25. Postoji i cijena neprovođenja lokalizacije, a to je nepovjerenje kupaca što u konačnici negativno doprinosi poslovnim prihodima te percepciji u javnosti. Poželjno je stoga iz poslovne perspektive uložiti u provođenje lokalizacije jer su pozitivni efekti veći od novčane investicije: veći prihodi, bolje javno prihvaćanje te pozitivan utjecaj na buduće pothvate tvrtke ${ }^{26}$. Globalno tržište i velika ulaganja u industriji digitalne zabave natjerali su programere i izdavače da svoje video igre prilagode i pripreme za mnoge druge jezike. Ne čudi stoga što je to je dovelo do novog područja specijalizacije u prevodilačkoj profesiji - „Iokalizacije video igara"27.

\section{Primjena procesa lokalizacija video igara}

Lokalizacija video igara odnosi se na pripremu video igre za prodaju u novoj regiji ili zem$\mathrm{lji}^{28}$. Na prvi pogled lokalizacija i prijevod video igara se možda ne razlikuju bitno od ostalih vrsta prijevoda. Postoje sličnosti i razlike u odnosu na lokalizaciju ostalih oblika softvera ${ }^{29}$, kao i audiovizualne lokalizacije kod koje je poseban naglasak na usmenoj kvaliteti dijaloga unutar video igre čime se želi zadržati izvorna razina kvalitete prilikom sinkronizacije i implementaciji titlova ${ }^{30}$. Lokalizacija video igara također je slična i procesu prevođenja dječjih

\footnotetext{
20 https://www.sinonim.hr/prevoditeljske-usluge/lokalizacija/

${ }^{21} \mathrm{https} / / /$ lokalise.com/blog/translation-and-localization-difference/\#Gaming

22 Ibid.

${ }^{23}$ https://www.sinonim.hr/blog/4718-2/

${ }^{24}$ https://blog.languageline.com/what-is-localization

25 https://www.prevoditelj-teksta.com/sto-je-lokalizacija/

26 Bernal Merino, M. (2008.) CREATIVITY IN THE TRANSLATION OF VIDEO GAMES, Quaderns de Filologia, Estudis Literaris, God. 13, str. 57-70

27 Bernal Merino, M. (2006.) On the Translation of Video Games, The Journal of Specialised Translation, God. 6, str. 22-36

28 Ibid.

29 Esselink, B. (2000.), A Practical Guide to Localization, John Benjamins Publishing Company, Amsterdam/Philadelphia

30 http://www.wordlabtranslations.com/download/its_a_funny_game_EN.pdf
} 
knjiga, posebno ako se uzme u obzir maštovitost prijevoda koju zahtijevaju dječje knjige, budući da se slična inovativnost traži i od prevoditelja koji rade na lokalizaciji video igara ${ }^{31}$.

No, u kontekstu video igara kombinacija teksta unutar istog proizvoda jedna je od karakteristika koja prijevod video igara razlikuje od prijevoda ostalih proizvoda. Specifični tekstovi dijele se na različite elemente: tekst unutar same video igre, umjetnički elementi, sinkronizacija glasa i odabir glasa općenito, titlovi itd. lako je prijevod samog teksta iz video igre veliki dio procesa lokalizacije, sam postupak uključuje i druge potrebne promjene u video igri. To može uključivati mijenjanje slikovnog prikaza, stvaranje novih pakiranja i priručnika, snimanje novog zvuka, prilagođavanja i transformiranje hardvera, uklanjanje nekih dijelova video igre zbog različitih kulturnih osjetljivosti i/ili zbog lokalnih pravnih zahtjeva i ograničenja te dodavanje dijelova koji zamjenjuju taj sadržaj ${ }^{32}$. Navedeno se provodi jer su svrha i cilj lokalizacije video igara priprema inačice vjerne izvornom materijalu koja je istovremeno prilagođena specifičnom kulturnom kontekstu krajnjih korisnika, kako bi iskustvo igranja bilo ugodno za igrača.

Zadovoljstvo igrača najvažniji je čimbenik cijelog procesa lokalizacije: ako igrač ima osjećaj i dojam da proizvod nije namijenjen njemu, ili ako lokalizacija stvara zbunjenost ili poteškoće u razumijevanju igre, to može umanjiti doživljaj igre te poremetiti sposobnost igrača da nastavi s konzumacijom video igre ${ }^{33}$. Stoga je važno osigurati da lokalizirana inačica pruža istu razinu kvalitete kao i izvorna video igra: dijalog, likovi i grafički elementi moraju biti predstavljeni točno onako kako je prvotno namijenjeno ${ }^{34}$. Uvijek treba osigurati da lokalizirana video igra radi besprijekorno na prevedenom jeziku ${ }^{35}$, jer je prijevod presudan za krajnje korisnike ${ }^{36}$ koji, bez obzira na kulturu i pozadinu, trebaju imati osjećaj da se radi o izvornoj varijanti video igre ${ }^{37}$.

\subsection{Proces lokalizacije video igara}

Prije iniciranja procesa lokalizacije potrebno je odrediti koja se vrsta lokalizacije treba provesti u sklopu lokalizacijskog projekta neke video igre. U tom kontekstu mogu se spomenuti lingvistička i kulturna lokalizacija koja se tiče prijevoda jezičnih i kulturnih referenci koje održavaju osjećaj video igre ali ju čine privlačnijim za ciljni jezik. Video igra se također može učiniti privlačnijom lokaliziranjem hardvera i softvera, tj. ponovnim mapiranjem interaktivnih tipki, modifikacijom samog igranja i slično. Grafika i glazba također su elementi koji utječu na konačan dojam lokalizirane inačice. Neke video igre mogu prikazivati različite likove ili pak iste s malo izmijenjenim izgledom kako bi se igračima omogućila identifikacija s njima.

Glazba ima utjecaj na završni dojam budući da se može razlikovati u skladu s nacionalnim trendovima ili preferencijama ciljanog tržišta. Pored navedenih elemenata također je važno biti svjestan potrebnih zakonskih prilagodbi jer se, npr. dobne granice mogu razlikovati od zemlje do zemlje te njihove promjene imaju utjecaj na elemente koji se smiju ili ne smiju uključiti, ili pak mogu potpuno promijeniti ciljnu publiku i korisnike.

31 Bernal Merino, M. (2008.) CREATIVITY IN THE TRANSLATION OF VIDEO GAMES, Quaderns de Filologia, Estudis Literaris, God. 13, str. 57-70

32 Bernal Merino, M. (2006.) On the Translation of Video Games, The Journal of Specialised Translation, God. 6, str. 22-36

33 O'Hagan, M. i Mangiron, C. (2013.), Game Localization, John Benjamins Publishing Company, Amsterdam/Philadelphia

${ }^{34}$ https://blog.andovar.com/games-translation-ultimate-guide

35 https://www.ecinnovations.com/blog/the-translation-of-video-games-requires-playability/

$36 \mathrm{https}$ ///scholarworks.umass.edu/cgi/viewcontent.cgi?article=1218\&context=masters_theses_2

37 Bernal Merino, M. (2008.) CREATIVITY IN THE TRANSLATION OF VIDEO GAMES, Quaderns de Filologia, Estudis Literaris, God. 13, str. 57-70 


\subsubsection{Razine lokalizacije video igre}

Prije provođenja projekta lokalizacije i prijevoda video igre nužno je znati do koje razine se želi provesti lokalizacija. Prva razina ne uključuje provođenje lokalizacije uopće, jer se video igra i dalje može plasirati u nekoj sredini ili zemlji na izvornom jeziku ako za nju postoji potencijalno tržište; ovdje se neće pristupiti lokalizaciji jer se time smanjuju troškovi.

Druga razina odnosi se na lokaliziranje pakiranja, omota, priručnika i ostale dokumentacije proizvoda, ali ne i same video igre. Ovakva razina lokalizacije može se koristiti ako video igra ima malo teksta ili manji broj popratnih priča i dijaloga, ili ako se očekuje da ciljano tržište ima dobru razinu shvaćanja i razumijevanja izvornog jezika video igre. To je često slučaj s uvozom video igara na engleskom jeziku.

Treća razina lokalizacije jest djelomična lokalizacija u kojoj se prevodi tekst igre, no ne i govorna gluma. Ovakav način lokalizacije pomaže u smanjenju troškova koji se javljaju prilikom zapošljavanja govornih glumaca i ponovnog snimanja cijelog dijaloga, a istovremeno čini igru razumljivom na drugom jeziku. Glasovni dijalog koji se ne pojavljuje na zaslonu može se lokalizirati uvođenjem titlova.

Posljednja razina lokalizacije predstavlja punu lokalizaciju, i ovdje se prevode svi elementi video igre, uključujući glasovni dijalog, tekst koji se javlja unutar video igre, grafiku, priručnike i ostalo. Ova opcija je najbolja, ali ujedno i najskuplja razina lokalizacije ${ }^{38}$.

\subsubsection{Načini prijevoda}

Lokalizacija općenito varira između dva pola: izvorne i ciljne kulture, nepoznatoga, tj. stranoga i poznatoga, doslovnog prijevoda od riječi do riječi i slobodne prilagodbe prijevoda, adekvatnosti i prihvatljivosti prijevoda ${ }^{39}$. Zbog ovoga se prevoditeljima daje sloboda da samostalno izmijene, prilagode, uklone kulturne reference, igre riječi i šale koje ne djeluju na isti način na ciljnom jeziku. Prevoditeljima je dana sloboda uključivanja novih kulturnih referenci, šala ili bilo kojeg drugog elementa koji smatraju potrebnim za očuvanje iskustva video igre i za stvaranje zanimljivog prijevoda ${ }^{40}$.

Ovdje do izražaja dolaze kreativni prijevodi te se prevoditelje potiče na primjenu uzbudljivih prijevoda koji se uklapaju u video igru i kojima se poboljšava iskustvo igrača za ciljani jezik i kulturu ${ }^{41}$. Prijevod stoga treba više biti sličan kreativnom pisanju nego doslovnom prijevodu, ali istovremeno treba prenijeti sve informacije sadržane u izvornoj inačici. Ta kreativnost koja je potrebna za lokalizaciju video igara omogućava igračima uživanje u iskustvu video igre i svim povezanim aktivnostima, bez da ih odvlače problemi kao što su loš prijevod ili nerazumljivo korisničko sučelje.

No, ne zahtijevaju sve video igre jednaku količinu promjena, ali određene prilagodbe učinit će da igrači više uživaju u igranju lokalizirane inačice. U jednom radu iz 2008. godine navodi se primjer lokalizacije japanske video igre „Final Fantasy“. Prikazan je primjer katane

\footnotetext{
38 Maxwell Chandler, H. i O'Malley Deming, S. (2012.), The Game Localization Handbook (2. ed.), Jones \& Barlett Learning

39 Bernal Merino, M. (2006.) On the Translation of Video Games, The Journal of Specialised Translation, God. 6, str. 22-36

40 Mangiron, C. i O'Hagan, M. (2006.) Game Localisation: Unleashing Imagination with "Restricted" Translation, The Journal of Specialised Translation, God. 6, str. 10-21

${ }^{41}$ Bernal Merino, M. (2006.) On the Translation of Video Games, The Journal of Specialised Translation, God. 6, str. 22-36
} 
nazvane 花鳥 風月 (kachōfūgetsu). Navedeno znači „,cvijet, ptica, vjetar i mjesec“, izraz koji se na japanskom jeziku koristi kao pojam „ljepote prirode“. Prijevod za američko tržište za ovo oružje bilo je „Painkiller“. Ovaj prijevod može se činiti čudnim ili pogrešnim, no utvrđeno je da je primjeren jer se smatra usklađenim s američkom kulturom video igara, što ga je učinilo potpuno valjanim ${ }^{42}$.

To ipak ne znači da i doslovan prijevod ponekad nije prihvatljiv, naprotiv, to je vrlo dobar pristup u prevođenju video igara kada se prevode već utvrđene riječi i termini, kao npr. neki tehnički izrazi ili specifična terminologija u primjerice trkaćim video igrama. U svakom slučaju, i kod izravnog i kod kreativnijeg prevođenja važno je da se u konačnici provede određena razina kontrole kvalitete i izvrši testiranje kako bi se osigurala kvaliteta prijevoda. To prvenstveno podrazumijeva testiranje video igre na prevedenom jeziku jer se tako mogu primijetiti pogreške i uočiti nedosljednosti ${ }^{43}$.

\subsubsection{Modeli proizvodnje prijevoda i provođenja lokalizacije}

Za provođenje odabrane razine lokalizacije mogu se koristiti različiti modeli proizvodnje prijevoda: obično je to interna ili pak vanjska proizvodnja. Odluka o lokalizaciji video igre uvelike se oslanja na ekonomske čimbenike, poput potencijalne dobiti koja bi se mogla ostvariti na novom tržištu ${ }^{44}$. Kao takav, postupak lokalizacije obično poduzima sama tvrtka pod kojom se video igra izrađuje ili ju poduzima neovisna prevoditeljska tvrtka. U slučaju da je službeni prijevod u konačnici loše kvalitete ili da službeni prijevod uopće ne postoji, može se pojaviti i neslužbeni prijevod video igre koji realiziraju sami igrači, tj. obožavatelji video igre.

U vanjskoj proizvodnji angažirana je tvrtka koja se bavi prevođenjem video igara i takva specijalizirana tvrtka provodi cijeli postupak lokalizacije ${ }^{45}$. Vanjske tvrtke angažirane za lokalizaciju često nemaju cijelu ili konačnu inačicu video igre na raspolaganju, već lokalizaciju izvršavaju nad dijelovima teksta ili umjetnosti video igre. Ovo rezultira tzv. „slijepom lokalizacijom" (engl. blind localization) ${ }^{46}$. U slijepoj lokalizaciji dostupna je samo ograničena količina informacija o završnoj inačici video igri, što rezultira nedostatkom konteksta koji može omesti proces lokalizacije. Da bi se ovo izbjeglo tvrtke prevoditeljima šalju "skoro dovršene“ inačice video igre kako bi i sami imali priliku istestirati video igru i na taj način bolje razumjeli kontekst ${ }^{47}$. U slučaju da navedeno nije moguće, tvrtka i izdavači će prevoditelje opskrbiti s "kompletom za lokalizaciju" (engl. localization kit). Komplet za lokalizaciju može sadržavati elemente kao što su opće informacije o projektu (uključujući rokove, budžet, popis ključnih točaka, kontaktne podatke, detalje softvera, detalje hardvera i sl.), resurse o samoj video igri (demonstracija o igranju, opis radnje ili likova), referentni materijali (pojmovnici termina koji se koriste u video igri ili koji se koriste za određeni hardver), elemente koji treba prevesti (tekstualne datoteke, grafike, audio i slično) i slično. Takav komplet definira glas, ton, smjer,

\footnotetext{
42 Bernal Merino, M. (2008.) CREATIVITY IN THE TRANSLATION OF VIDEO GAMES, Quaderns de Filologia, Estudis Literaris, God. 13 , str. $57-70$

43 https://www.sinonim.hr/blog/4718-2/

44 O'Hagan, M. i Mangiron, C. (2013.), Game Localization, John Benjamins Publishing Company, Amsterdam/Philadelphia

45 lbid.

${ }^{46}$ https://www.raco.cat/index.php/Tradumatica/article/download/75763/96193/0

47 O'Hagan, M. i Mangiron, C. (2013.), Game Localization, John Benjamins Publishing Company, Amsterdam/Philadelphia
} 
stil prevođenja i sl. U slučaju da prevoditelji nemaju nijednu inačicu video igre ni komplet za lokalizaciju na raspolaganju, to može ozbiljno naškoditi procesu prevođenja i lokalizacije ${ }^{48}$.

Kao alternativa vanjskoj proizvodnji, prevoditelji se mogu angažirati i interno. U ovom modelu je proces lokalizacije pod kontrolom tvrtke koja razvija video igru. Prevoditelji koji rade u sklopu ovog modela na raspolaganju imaju komplet za lokalizaciju, ali imaju i bolji pristup samoj video igri. Ovo može do određene razine osigurati da prijevod ima manje kontekstualnih pogrešaka i rezultira sveukupno boljim tijekom lokalizacije. Negativna strana ovog načina proizvodnje je vremenska razlika između izlaska igre na izvornom jeziku i u naknadnom izlasku lokalizirane inačice video igre, što je posebno zabrinjavajuće u kontekstu globalnog tržišta ${ }^{49}$.

Posljednji modus lokaliziranja video igre jest putem (neovlaštenog) truda obožavatelja neke video igre. Postoji velik broj obožavatelja i igrača koji su spremni uložiti veliku količinu neplaćenog rada i vremena kako bi lokalizirali video igru koja bi inače ostala nedostupna. Ako je izdavač video igre odlučio da video igra neće biti lokalizirana za određeno tržište, npr. zbog sumnje u ostvarenje profita, neki igrači se mogu samostalno angažirati i objaviti prijevod. Ovo se također može dogoditi ukoliko postoji službena lokalizacija koja nije prihvaćena od strane igrača, prvenstveno zbog svoje loše kvalitete ${ }^{50}$.

\subsubsection{Modeli otpreme lokalizacije}

Provedene lokalizacije uglavnom pripadaju jednom od dva ključna modela otpreme: post-gold ili sim-ship. Model lokalizacije post-gold poduzima se kada je izvorna video igra već dovršena i obično je već objavljena. Kao rezultat postoji zastoj između objavljivanja izvornika i lokaliziranih inačica video igre ${ }^{51}$. Post-gold model omogućava prevoditeljima pristup dovršenoj igri umjesto da rade s nepotpunom i nedovršenom video igrom i općenito omogućuje više vremena za dovršavanje prijevoda pa se stoga primjenom ove metode generira manji broj pogrešaka u prijevodu ${ }^{52}$.

Model sim-ship ili istovremene isporuke (engl. simultaneous shipment), omogućuje istovremeno objavljivanje video igre u više regija ili za više različitih tržišta. Budući da video igre imaju relativno kratko razdoblje prodaje, s obzirom da su podložne ilegalnom piratstvu, postoji financijski poticaj za istovremeno objavljivanje video igre širom svijeta ${ }^{53}$. Međutim, provođenjem ove metode postoji vrlo mala vjerojatnost da će dovršena verzija video igre biti dostupna prevoditeljima, što u konačnici rezultira većom vjerojatnošću pojavljivanja pogrešaka u prijevodu, budući da presudni podaci o kontekstu i samoj video igri mogu nedostajati ${ }^{54}$.

\footnotetext{
48 Ibid.

49 Ibid.

50 Bernal-Merino, M. (2009.) Video games and children's books in translation, The Journal of Specialised Translation, God. 11, str. 234-247

51 O'Hagan, M. i Mangiron, C. (2013.), Game Localization, John Benjamins Publishing Company, Amsterdam/Philadelphia

52 Ibid.

53 Maxwell Chandler, H. i O'Malley Deming, S. (2012.). The Game Localization Handbook (2. ed.), Jones \& Barlett Learning

${ }^{54}$ O’Hagan, M. i Mangiron, C. (2013.), Game Localization, John Benjamins Publishing Company, Amsterdam/Philadelphia
} 


\subsection{Problemi u procesu lokalizacije video igara}

Tijekom cijelog procesa lokalizacije postoji mogućnost pojavljivanja raznih problema, jer je sam proces lokalizacije vrlo izazovan bez obzira o vrsti lokalizacijskog projekta koji se provodi. Npr. različite vrste teksta zahtijevaju različit odnos i način prevođenja, a ako sam tekst nije problematičan, probleme mogu stvarati zbunjujuće korisničko sučelje, loša glasovna gluma i slično ${ }^{55}$.

Mnogo je različitih problema koji se javljaju prilikom lokalizacije video igara za strana tržišta ${ }^{56}$. Jedna od najčešćih pritužbi je nedostatak kvalitete prijevoda i kako se igrači ponekad moraju vratiti na izvornu inačicu kako bi saznali što i kako nešto učiniti u određenom trenutku igre. U mnogim slučajevima obožavatelji nisu impresionirani lokalizacijom, jer loša kvaliteta poništava glavnu svrhu: oduševiti igrača. Nekvalitetno provedena lokalizacija može biti gora od djelomične ili nikakve, zbog očekivanja koja ona postavlja. To se dogodilo sa španjolskim izdanjem video igre „Elder Scrolls IV: Oblivion“, gdje je po količini pogrešaka bilo očito da se nije provelo testiranje. Skupina igrača ujedinila se i nekoliko mjeseci kasnije objavila zakrpu sa znatno poboljšanim prijevodom. Nešto slično ponovilo se sa španjolskom lokalizacijom video igre „Age of Pirates: Caribbean Tales“. Prijevod tada nije bio problem, no kvaliteta sinkronizacije jest. Igrači su smatrali da glasovni glumci zvuče neprofesionalno, tako da su se igrači okupili i proizveli novi prijevod za poboljšanje službene španjolske inačice ${ }^{57}$. Navedeni primjeri ilustriraju kako igračima nije bitno približiti samo jezik, već i likove i čitavo iskustvo igre ${ }^{58}$.

Drugim riječima, meksički, francuski ili kineski igrač trebao bi uživati u igranju i imati jednako iskustvo kao netko tko igra izvornu inačicu video igre ${ }^{59,60}$. No, ovo se ponekad jednostavno ne može ostvariti zbog primjerice ranije navedene slijepe lokalizacije. Od mnogih prevoditelja traži se da rade na temelju "gole" proračunske tablice ${ }^{61}$. U radu iz 2008. godine navodi se nekoliko primjera koji pokazuju kako ovakav pristup prevođenju može biti nezgodan i frustrirajuć za prevoditelja:,/'m not sure I can make this much clearer ..." i, You ready to go?" dva su niza dijaloga koji, prevedeni na francuski, talijanski, njemački ili španjolski, ilustriraju neke od ovih problema. U prvom primjeru nemoguće je znati je li govornik muško ili žensko. U drugom slučaju, prevoditelj može samo nagađati obraća li se govornik jednoj osobi ili više pojedinaca, i je li odnos između njih formalan ili neformalan ${ }^{62}$. Probleme može stvarati i sama radnja video igre, jer ako su video igre više vođene pričom, njihova lokalizacija može biti izazovna zbog utjecaja okoline i načina razvoja radnje unutar igre. Npr. prilikom prikaza krvi i stvarnih povijesnih događaja se mnoge činjenice moraju prilagoditi kako bi se uklopile u zakonske okvire i toleranciju zemlje kako se ne bi uvrijedilo ciljano tržište. Pretpostavlja se da je to vjerojatno jedan od razloga zašto se toliko igara odvija u zamišljenim svjetovima63.

\footnotetext{
55 Bernal Merino, M. (2008.) CREATIVITY IN THE TRANSLATION OF VIDEO GAMES, Quaderns de Filologia, Estudis Literaris, God. 13 , str. $57-70$

56 Ibid.

57 lbid.

58 Ibid.

59 Costales, A. F. (2012.) Exploring Translation Strategies in Video Game Localization, MonTi Monografías de Traducción e Interpretación, str. 358-408

60 Maxwell Chandler, H. i O'Malley Deming, S. (2012.), The Game Localization Handbook (2. ed.), Jones \& Barlett Learning

61 http://www.wordlabtranslations.com/download/its_a_funny_game_EN.pdf

62 Bernal Merino, M. (2008.) CREATIVITY IN THE TRANSLATION OF VIDEO GAMES, Quaderns de Filologia, Estudis Literaris, God. 13, str. 57-70

63 Ibid.
} 
Stoga će prijevod u nekim slučajevima biti stvarna rekreacija, tj. „transkreacija“, gdje se od prevoditelja očekuje da prevedu tekst s pravim „osjećajem“ za ciljano tržište. Za razliku od većine oblika prevođenja, video igre mogu prilagoditi i izmijeniti izvorni tekst ako to u konačnici donosi veću zabavu i igrivost u ciljanoj kulturi ili sredini ${ }^{64}$. Upravo taj faktor, igrivost, potreban je da bi video igra postigla potpunu uronjenost nakon što je prevedena i treba je kvalitetno održavati kako bi se igračima omogućilo uvjerljivo iskustvo. No, lokalizacija se ne odnosi samo na prevođenje sadržaja za određeno tržište s ciljem prodaje, već se odnosi i na osiguranje da video igra zaista i besprijekorno radi na prevedenom jeziku ${ }^{65}$. Glavni prioritet lokalizacije igre je očuvanje iskustva igranja za ciljane igrače, zadržavajući izgled i dojam izvornika. Zadatak predvoditelja je oblikovati inačicu na način koji će omogućiti igračima doživljaj igre kao da je izvorno razvijena za njihov jezik. Da bi se to postiglo, presudno je da prevoditelji budu upoznati s domenom igre. Moraju biti svjesni gradivnih dijelova igara, terminologija, vrsta humora prisutnih u igri, uporaba igre riječi itd. Također moraju biti u stanju prepoznati aluzije i intertekstualne reference na druge žanrove globalne popularne kulture, poput stripova i filmova ${ }^{66}$.

Navedeno može predstavljati probleme jer se video igre često oslanjaju na različite elemente popularne kulture kao što su filmovi, književnost, stripovi, TV emisije ili sport. Kada se ovo dogodi, za prijevod teksta potrebno je razumijevanje korištenog žargona i precizno prevođenje terminologije. Ako je igra izvedba Sherlocka Holmesa prema autoru A. Conana Doylea, prvi korak za prevoditelje bio bi upoznavanje sa službenim prijevodom knjiga, kao i filmova i stripova. U ovom slučaju nema puno slobode; prevoditelji su ograničeni već postojećim općim znanjem i skupom obožavatelja koja imaju vrlo specifična očekivanja. Nepoštivanje tih očekivanja putem lokalizacije koja zanemaruje postojeći poznati prijevod vjerojatno će se loše odraziti na iskustvo video igre, izazvati nezadovoljstvo obožavatelja, loše recenzije, a time i slabu prodaju. Stoga je potrebno u proces lokalizacije uključiti detaljno popisivanja konkretnih likova i imena, evidentiranje koncepata i ideja, testiranje igre igranjem svih područja, razina i načina igre, čitanje pozadinske dokumentacije i istraživanje ranije lokaliziranih inačica video igre.

S druge strane, ako se igra temelji na potpuno novoj ideji ili novoj za ciljni jezik, stupanj slobode je poprilično velik i omogućuje relativno kreativan pristup lokalizaciji. Ipak, niti jedna video igra nije proizvedena u "vakuumu“, sve one mogu imati elemente postojećih proizvoda, ali ograničenja su manje stroga kada se prevodi novi koncept ${ }^{67}$.

Pravi izazov za prevoditelje video igara je uspostavljanje ravnoteže između različitih stilova pisanja i prevođenja potrebnih u različitim inačicama igre. Tipična video igra sadržavat će sirovi tekst u korisničkom sučelju, priručniku za igru i sustavu pomoći; ali sadržavat će i kreativno pisanje u priči i audio scenariju. Pružanje kvalitetnih prijevoda u različitim stilovima posebna je vještina. To znači da prevoditelji moraju oduševiti igrače koji pripadaju drugim kulturama, i pokrenuti ih pričama i likovima igre tako da mogu doći do ugodnog i uspješnog

\footnotetext{
${ }^{64}$ Ibid.

${ }^{65} \mathrm{https} / / /$ www.ecinnovations.com/blog/the-translation-of-video-games-requires-playability/

${ }^{66}$ Mangiron, C. i O'Hagan, M. (2006.) Game Localisation: Unleashing Imagination with "Restricted" Translation, The Journal of Specialised Translation, God. 6, str. 10-21

${ }^{67}$ Bernal Merino, M. (2008.) CREATIVITY IN THE TRANSLATION OF VIDEO GAMES, Quaderns de Filologia, Estudis Literaris, God. 13 , str. $57-70$
} 
završetka video igre ${ }^{68}$. Sama igrivost nikada ne smije biti umanjena zbog loše glasovne glume, nejasnih izbornika, zbunjujućih uputa, nekvalitetnog prijevoda i drugih pogrešaka u lokalizaciji ${ }^{69}$.

\section{Stanje na hrvatskom tržištu}

Lokalizacija video igara prisutna je i na hrvatskom tržištu, a sam proces i način njenog provođenja mogu se promatrati putem nekih od popularnih, nedavno lokaliziranih video igara kao što su God of War (2018.), Days Gone (2019.), Detroit: Become Human (2018.) te MediEvil (2019.) ${ }^{70}$ Svaka od navedenih video igara provodi djelomičnu lokalizaciju za hrvatsko tržište. Na temelju navedenoga može se zaključiti da se lokalizacija video igara za hrvatsko tržište bazira na prijevodu samog korisničkog sučelja te na uvođenju ili prevođenju titlova. Rijetko će se za hrvatsku lokaliziranu inačicu naći i popratna glasovna gluma. Također, iako je preporučeno da se određene značajke video igre prilagode za ciljano tržište, u praksi se na hrvatskom tržištu to u većini slučajeva ne može zapaziti. Ovu činjenicu moguće je obrazložiti općenitim smanjenjem troškova prilikom prilagodbe drugim tržištima, no isto tako se može argumentirati da medu samim hrvatskim igračima ne postoji dovoljno interesa. $U$ anketi provedenoj na $\mathrm{HCL}$ platformi ${ }^{71}$ rezultati ukazuju da samo 37,75\% igrača igra hrvatske inačice video igara te da se igrači općenito protive lokaliziranim inačicama video igara za hrvatski jezik. Lako je uočiti da hrvatski igrači preferiraju izvorna, engleska izdanja. Ovo olakšava proces lokalizacije budući da hrvatsko tržište ne zahtijeva posebne dorade, a sama video igra se ne treba prilagoditi navikama hrvatskih igrača, već samo posebnim prikazima, poput prikaza domaćih valuta. Stoga je moguće pretpostaviti da je djelomična lokalizacija sasvim dovoljna za hrvatsko tržište. Navedeni preferirani način igranja na engleskom jeziku toliko je zastupljen da se i video igre hrvatskih proizvođača ponekad ne lokaliziraju na hrvatski jezik. Video igra „Scum”, izdana 2018. godine proizvođača „Gamepires“, primjer je nedavno izdane i vrlo popularne hrvatske video igre koja nema službeni hrvatski prijevod, već se koristi engleskim jezikom kao izvornim. Pored izvorne engleske inačice popraćena je i s deset djelomično lokaliziranih izdanja ${ }^{72}$. lako se ova pojava čini neobičnom, lako se može obrazložiti željom da video igra bude dostupna što većem broju igrača, što engleski jezik omogućuje za razliku od hrvatskog jezika. Navedeni način osigurava dostupnost video igre većini tržišta, ne samo hrvatskom, što eliminira potrebu za dodatnim lokaliziranjem i njenim troškovima.

\section{Zaključak}

Budući da strana tržišta uvelike doprinose poslovnim rezultatima, izdavači video igara sve više obraćaju pažnje na načine na koje mogu povećati svoju prodaju na međunarodnom tržištu. Jedan od potencijalnih načina povećavanja prodaje je objavljivanjem međunarodnih inačica video igara koje su prevedene na nekoliko jezika i prilagođene ciljanom tržištu. Lokalizacija video igara je proces kojim se osigurava da video igra funkcionira na prevedenom jeziku bez

\footnotetext{
68 Ibid.

69 https://www.ecinnovations.com/blog/the-translation-of-video-games-requires-playability/

70 https://reboot.hr/remake-kultne-igre-medievil-na-ps4-dolazi-s-hrvatskim-prijevodom-i-lokalizacijom/

71 https://www.hcl.hr/ankete/anketa-igrate-li-igre-hrvatskom-jeziku-155666/

72 https://store.steampowered.com/app/513710/SCUM/
} 
smetnji i da obožavatelji mogu nesmetano uživati u njoj kao da se radi o izvornoj inačici. Video igre se obično prodaju širom svijeta, što znači da se moraju prilagoditi velikom broju jezika, kulturnim i geografskim razlikama, načinima govora i razmišljanja i slično. Pored navedenog, lokalizacija video igara uključuje i prilagođavanje video igre pravnim i drugim zahtjevima ciljanog jezika i tržišta, kao i brojnim kulturalnim nijansama koje su specifične za svako područje. Ona podrazumijeva prijevod teksta unutar video igre, audio materijala i drugih komponenti igre, no uključuje i prilagođavanje dizajna, korištenih boja, datuma, valuta i slično. Sve s ciljem da bi se održala sama igrivost video igre. Upravo je igrivost presudan čimbenik za lokalizaciju video igara, jer iako je možda glavna funkcionalnost prevedene igre jednaka onoj u izvornoj inačici, konačan dojam lokaliziranog proizvoda najviše ovisi o razini zadovoljstva krajnjih korisnika. Kod lokalizacije se mogu primijeniti različiti pristupi i modeli, i ona može uključivati izravne ili vrlo maštovite prijevode, no za uspješan dovršetak lokalizacijskog projekta svakako treba voditi računa o kontroli kvalitete, i ona se treba ispitivati za vrijeme, tijekom i nakon završetka lokalizacije video igre.

\section{LITERATURA}

1. Bernal Merino, M. (2006.) On the Translation of Video Games, The Journal of Specialised Translation, God. 6, str. 22-36

2. Bernal Merino, M. (2008.) CREATIVITY IN THE TRANSLATION OF VIDEO GAMES, Quaderns de Filologia, Estudis Literaris, God. 13, str. 57-70

3. Bernal-Merino, M. (2009.) Video games and children's books in translation, The Journal of Specialised Translation, God. 11, str. 234-247

4. Costales, A. F. (2012.) Exploring Translation Strategies in Video Game Localization, MonTi Monografías de Traducción e Interpretación, str. 358-408

5. Esselink, B. (2000.), A Practical Guide to Localization, John Benjamins Publishing Company, Amsterdam/Philadelphia

6. http://www.wordlabtranslations.com/download/its_a_funny_game_EN.pdf (pristup: 23. 04.2021.)

7. https://blog.andovar.com/games-translation-ultimate-guide (pristup: 22.04.2021.)

8. https://blog.languageline.com/what-is-localization (pristup: 22.04.2021.)

9. https://lektor.hr/hr/usluga/lokalizacija-7 (pristup: 22.04.2021.)

10. https://lokalise.com/blog/translation-and-localization-difference/\#Gaming (pristup: 22. 04.2021.)

11. https://reboot.hr/remake-kultne-igre-medievil-na-ps4-dolazi-s-hrvatskim-prijevodom-ilokalizacijom/ (pristup: 09.06.2021.)

12. https://scholarworks.umass.edu/cgi/viewcontent.cgi?article=1218\&context=masters_ theses_2 (pristup: 23.04.2021.)

13. https://searchcio.techtarget.com/definition/localization (pristup: 22.04.2021.)

14. https://store.steampowered.com/app/513710/SCUM/ (pristup: 09.06.2021.)

15. https://www.ecinnovations.com/blog/the-translation-of-video-games-requires-playability/ (pristup 23.04. 2021.) 
16. https://www.hcl.hr/ankete/anketa-igrate-li-igre-hrvatskom-jeziku-155666/ (pristup: 10. 06.2021.)

17. https://www.investopedia.com/terms/i/internationalization.asp (pristup: 22.04.2021.)

18. https://www.prevoditelj-teksta.com/sto-je-lokalizacija/ (pristup: 22.04.2021.)

19. https://www.raco.cat/index.php/Tradumatica/article/download/75763/96193/0 (pristup: 24.04.2021.)

20. https://www.sinonim.hr/blog/4718-2/ (pristup: 24.04.2021.)

21. https://www.sinonim.hr/prevoditeljske-usluge/lokalizacija/ (pristup: 20.04.2021.)

22. Mangiron, C. (2018.) Game on! Burning issues in game localisation, Journal of Audiovisual Translation, God. 1, Br. 1, str. 122-138

23. Mangiron, C. i O'Hagan, M. (2006.) Game Localisation: Unleashing Imagination with "Restricted" Translation, The Journal of Specialised Translation, God. 6, str. 10-21

24. Maxwell Chandler, H. i O'Malley Deming, S. (2012.), The Game Localization Handbook (2. ed.), Jones \& Barlett Learning

25. O’Hagan, M. i Mangiron, C. (2013.), Game Localization, John Benjamins Publishing Company, Amsterdam/Philadelphia

\section{Summary}

\section{APPLICATION AND SIGNIFICANCE OF THE VIDEO GAME LOCALIZATION PROCESS}

With the rapid development and great growth in popularity of video games, the video game industry has undergone a significant process of globalization in recent years. Video games are an essential factor in the digital entertainment industry today and attract many players, regardless of gender, age, social, political or economic status. This popularity and rapid development of video games is leading to the growing need for companies to make their video games available to as many people as possible in order to achieve a high return on financial investments. Therefore, there is an obvious desire and need for video games to be tailored to all potential users, wherever they are. This is an extremely important factor in player satisfaction, and as such is very important in overcoming the language barrier, promoting the company's international image and achieving good business results. But this means that the video game needs to be adapted to a large number of languages, cultural differences, ways of speaking and thinking, and at the same time to remove everything that is not suitable for the target market. One of the possible solutions for adapting to the international market is certainly localization, the application of which seeks to meet the needs of all players and markets. Video games, however, have specific features that distinguish them from other media, as they focus on player interactions and graphic elements of a game, which is unique compared to translating a novel or film. This paper provides an overview of video game adaptation strategies and the characteristics of the adaptation flow, with special emphasis on the localization approach as well as problems and open issues in the process of adapting video games to the international market.

Keywords: natural language processing, localization, internationalization, language technologies, video games. 